\title{
Reassessing (De)Standardisation: Life course trajectories across three generations
}

Sofia Aboim, Instituto de Ciências Sociais da Universidade de Lisboa

Pedro Vasconcelos, Iscte Instituto Universitário de Lisboa

\begin{abstract}
A central problem of life course analysis concerns the changes brought about by the pluralisation and differentiation of biographies in western societies. Lives would be increasingly dissimilar from each other and marked by a wider range of transitions and stages. Under the lens of life-course theorisation, the heterogenisation of biographies is normally understood as destandardisation. However, if the destandardisation hypothesis gained momentum, there is still little information about its explanatory power outside the richest centres of Europe and North America. Following recent trends in research, the article critically examines the applicability of the destandardisation hypothesis to the Portuguese case. Through an analysis of the lives of three generations of Portuguese men and women, we reconstruct the life trajectories of each generation starting from the 1930s until the early 2000s. Through the reconstitution of both family and work trajectories, we verify if there was at any given moment a standard biography from which to derive subsequent patterns of heterogenisation. From this perspective, we reassess the extent to which the destandardisation model is fitted to explain life course transformations in Portuguese society.
\end{abstract}

Key Words: destandardisation; life course; family and work trajectories; individualisation; modernity. 


\section{Introduction}

A central problem of life course analysis concerns the changes brought about by the pluralisation and differentiation of biographies in western societies. While the problem of change in life course patterns led to important conceptual developments, the main hypothesis for explaining biographical transformations established that contemporary post-industrial societies harbour a greater diversity of life paths and lifestyles. Rather than a typical biography that applies to everyone, individuals would now be able to live their lives in more individualised manners giving way to a growing plurality in and within biographies. Lives would be more heterogeneous and standardisation would be in the downfall.

Occupying centre-stage in life course literature and conceptual baggage, standardisation is usually intended to measure the statistical homogeneity of life course states and events as well as the uniformity of transitions and sequences of durable stages in a given population (Brückner and Mayer 2005: 32). In contrast, destandardisation would signal the tendency for life states, events and their sequences to 'become experiences which either characterize an increasingly smaller part of a population or occur at more dispersed ages and with more dispersed durations' (Brückner and Mayer 2005: 32-33). As a statistical tool, destandardisation is, above all, a measure of dispersion and heterogeneity. In life course scholarship, the diversification of life courses is therefore understood as a process of destandardisation. However, destandardisation is often interwoven with a number of correlated concepts, which are often used interchangeably. In effect, it is difficult to perceive (des)standardisation as independent from processes of (de)institutionalisation, (de)individualisation, (un)differentiation or pluralisation versus homogenisation. Arguing against the excessive conceptual mix, Brückner and Mayer suggested that inasmuch as each concept measured a different dimension, they should be distinguished from each other. While 
distinctions are useful, this is hardly a simple task. Perhaps because the (des)standardisation concept cannot be reduced to a simple indicator or measure of biographical heterogeneity. Rather, it implies a number of concurrent processes either presented as correlated developments or as explanatory causes. In the latter perspective, destandardisation would simply reflect wider historical processes of social individualisation and differentiation (Elias 1993, Beck and Beck-Gernsheim 2002) as well as the combined impact of institutional regulations, welfare policies and economic developments upon the lives of individuals (Kohli 2007, Mayer 2004, Möhring 2016).

Against the background of long-term historical processes of social change, the destandardisation hypothesis gained momentum and has been greatly explored. However, in spite of its popularity and the wealth of research produced, there is still little information about processes of destandardisation outside the richest centres of Europe and North America. Following recent trends in scholarship and seeking to add information to the research already undertaken in Portugal (see Ramos 2016, and in particular, Ramos 2019), we further examine the applicability of the destandardisation hypothesis to the Portuguese case. We develop our approach along two lines of argumentation.

Firstly, while it seems obvious that the degree of biographical heterogeneity can easily be measured in Portugal (as already done by Ramos 2019), in our view, it is still important to look back before looking ahead. While recent findings demonstrate that both standardisation (homogenisation) and destandardisation (heterogenisation) coexist in the Portuguese context (Ramos 2019: 16), we believe that mapping the life course patterns prevailing in Portuguese society remains an important endeavour. In a nutshell, we need to further advance our knowledge of how people lived their lives, which families they constructed, what work situations they endured, which occupational paths they were able to 
pursue. With that objective in mind, following a bottom-up approach, we inductively reconstructed the family and work trajectories of three generations of Portuguese men and women. Although our statistical tools are purportedly descriptive, we sought to identify all the different types of trajectories within our three-generation sample, covering a period from the 1930s until the early 2000s. Through the reconstitution of life course trajectories we intended to find out if, at any given moment in time, there was a standard and homogenising biography from which to derive subsequent patterns of heterogenisation.

Secondly, confronted with the multiple and often blurry meanings of (de)standardisation, we opted then for tentatively working with the simpler notion of plurality as a proxy for destandardisation. By prioritising plurality, we are not, in fact, distant from a vast number of studies, which examined the hypothesis of the greater complexity of life courses in late modernity and concluded that the pluralisation of life courses had been slower and weaker than firstly predicted (Brückner and Mayer 2004). Additionally, we do not ignore the possibility that rather than affecting the whole population uniformly (Möhring 2016), biographical pluralisation may apply to smaller groups (Widmer and Ritschard 2009). In the face of the limited occurrence of destandardisation (also in the Portuguese case, according to Ramos 2019), we suggest that the concept would benefit from further reassessment. On the one hand, if (des)standardisation is an outcome of a number of key social transformations in life course policies (including institutionalised individualisation and age regulation), we have to be cautious when using measures of statistical dispersion. After all, the homogenisation of schooling careers, the augmented labour precariousness or the expansion of conjugal cohabitation might well be new standards within a life course regime that is strikingly different from past biographical regimes. On the other hand, it is important to avoid the oftencommon conflation between statistical dispersion for measuring biographical plurality and 
the idealisation of a normal (or standard) biography. Usually, echoing central tenets of Parsonian functionalism and older ideations of a linear and conservative life cycle based on marriage and full employment, the standard against which all other trajectories are measured replicates a model of life afar from the reality of biographies in most geographic locations and historical periods. From the perspective of Parsons, individualisation would be essentially anti-organicist and potentially dismembering of the functional order. As Alexander (2014: 120) rightly contends, Parsons 'views the life cycle as a bridge between the normative and conditional institutions of society'. Until today, and in spite of all theoretical and empirical worth of life course scholarship, the risk of overly conflating a given normative biography with the standard should not be ignored.

Against this backdrop, we reassess the extent to which the (de)standardisation model built upon the historical pathway of other societies - usually richer and with an earlier process of modernisation that developed from the post-WII period to the $1970 \mathrm{~s}$ - is fitted to describe life course transformations in Portuguese society. In the section that follows, we relocate the concerns with the changes in life course patterns in the broader context of social individualisation and theorisations about modernity. From this angle, we seek to deconstruct the ideation of a 'normal biography' that, even from behind the scenes, might contribute to the unintended mix between norms and empirical prevalence. When we ask ourselves, which biographical plurality we are dealing with, it might be fruitful to take a step back and further explore the meanings of homo and heterogenisation while building a conceptual framework that might contribute to expand our knowledge of Portugal and critically address the concept of (de)standardisation at large. 


\section{Life-course and modernity: framing the destandardisation hypothesis}

The transition from a phase of 'organised modernity', as Peter Wagner (1994) called it, to a new period marked by the detraditionalisation (Heelas 1996) of old linear life cycles - which were closely linked with almost predetermined identities and roles (Giele 2004) has nourished the debate around the pluralisation of present-day life courses (Giddens 1992, Bauman 2001, Beck and Beck-Gernsheim 2002). The proliferation of concepts related to the transformation of contemporary biographies is significant. Whether lives have become liquid (Bauman 2004), fragmented (Craib 1998), reflexive (Giddens 1992) or patchwork-based (Beck 2000) is definitely a sign of the times. Indeed, the growing individualisation of life paths (Mayer 2004) would have forced individuals to face the challenges imposed by the construction of malleable and plural life courses, which they often organised in the form of 'patchwork biographies' (Beck 2000:170). In the same vein, as a critical response to linear conceptions of the life cycle, quite popular in American sociology until the mid-1980s (e.g. Hill and Rogers 1964), life course scholarship tried to understand and explain the growing complexity of individual lives (Elder, Johnson and Crosnoe 2003).

Under the large umbrella of modernisation, the historical changes in life course patterns have not escaped heavy scrutiny, with analytical efforts often resulting in typologies of life course regimes over time. Mayer (2004) put one of the best-known proposals forward. The author and life course theorist identifies four different regimes. Before the 1900s, prevailed the traditional family economy model, in which the chronological organisation of life was poorly regulated. Governing the first half of the twentieth century, the industrial model was still structured by poverty and a degree of unpredictability coupled with emerging levels of standardised schooling and family organisation. The Fordist model, which stretched from the post-war period to the 1970s, represented the peak of life-course standardisation 
and institutionalisation prompted by the strong economic regulation and the expansion of the welfare state. Finally, developing from the mid-1970s onwards, the post-Fordist or postindustrial model is defined by the destandardisation (or pluralisation within a population) and differentiation of individual life courses under the ideological banner of hedonist individualism.

The truth is that in the peak of organised modernity, Fordist life courses were expected to obey structured and sequential stages from childhood to old age. Schooling careers, progressively longer, would be followed by the entrance into the labour market, marriage and parenthood, thus signalling the transition to a well-defined and stable adulthood. At a later stage, the life cycle would be complete with the arrival of grandchildren, retirement and the entry into old age. Linear transitions between each stage would inaugurate new chronological phases designed to match specific roles and statuses. Within the Fordist life course regime prompted by the institutional conditions of organised modernity, the chronological regime of biographies brought age differences (alongside gender or social class) to the centre of social differentiation processes (Heinz and Kruger 2001: 33). However, as well noted by Brückner and Mayer (2005), the historical period of strong patterning of life courses was brief and geographically localised in Western Europe and North America. Replacing the instability of life courses in the pre-modern period, the Fordist life course regime was the historical exception in the aftermath of WWII. From the mid-1970s onwards, a new historical time marked by de-linearisation (Pais 2001) was inaugurated, marking the end of a very short historical period. However, although the standardised period was much shorter than usually imagined, the effects it produced were manifest. Until today, the destandardisation hypothesis is, after all, a measure of the transition from the Fordist to the post-Fordist life course regime. 
In response to the concern with the tensions generated by institutionalised individualism (paraphrasing Beck 2002), in the mid-1980s Kohli (1986: 272) argued that the life course had turned itself into an institution that organises biographies and offers a response with the potential instability created by individualisation dynamics. In effect, the argument put forward by Kohli (1986) proposed the alliance between individualisation and standardisation of the life course from the late nineteenth century onwards. For the author, the greater variability of individual life courses was not contradictory with the modern chronology-based standardisation (Kohli 2007: 255). Individualisation and standardisation would reflect the modernisation of societies, particularly with regard to changes in the labour market and the regulatory impact of the State (Mayer and Muller 1986). Empirical evidence suggested, at the time and especially from the 1960s onwards, that the transition to adult life had become simultaneously more individualised and standardised due to the combined effect of the public regulation of age with the growing diversification of life courses (Hogan 1981). In a more recent article, Kohli (2007) acknowledged the dramatic changes that occurred since the 1980s but defended still his original thesis.

Nonetheless, Kohli pinpointed the growing tension between standardisation and individualisation. As the author asserted: 'For the institutionalised life course (...) one source of potential instability is the tension between the standardised life-course program and the claims for individualisation and biographisation, which are increasingly institutionalised as a legitimate and even normatively required way of life' (Kohli 2007: 257). The concern with the effects of individualisation, whether enabling or disruptive, feeds a central agenda for research within the studies of the life course, which resembles the preoccupation with the passage from modernity to post or late modernity. More, the concern with the effects of individualisation is akin to Weber's, Durkheim's or Marx's preoccupation with social change 
and the consequences of industrialisation back in the nineteenth century. The resilience of classificatory schemes of thought about the traditional past versus the uncertain future seems to be as foundational as cyclic in sociological reflections about social change. Historical analyses show, however, that we are often measuring the present and the future against a past that never was. After all, modernity and modernisation were neither chronologically linear nor internally coherent (see Therborn 2003). A similar reasoning fits well with life course regimes or their historical development, which seems, above all, to depict the mix between different biographical models and concurrent social processes. In this sense, measuring processes of pluralisation can be a difficult endeavour and a consensual explanation hard to achieve. In particular, when lives are affected by multiple and many-sided developments.

Overall, processes of individualisation and differentiation typical of late modernity are usually deemed to produce, and explain, destandardisation. As noted by Kohli (1986), modern individualisation forged the plurality of individual life courses, enlarging the range of possibilities and choices. However, rather than anomic, pluralisation sits on a wellstructured age codification system. Life stages and biographical events are limited by legal and institutional regulations, which define the ages for attending school, entering the labour market, getting married, retiring and being young or old. One major consequence of modernity's social temporalisation (Giddens 1992, Abbott 2001) translates precisely into the 'chronologicalisation' of individual lives through formal institutional mechanisms. In all societies, there are specific forms of organising life stages by connecting them with particular normative social roles (Kertzer 1989: 5). Notwithstanding, in the words of Kholi, tensions between public standardisation and social individualisation are likely to be on the rise, making it difficult to define a socially dominant and normalised path (Shanahan 2000). 
A number of authors have questioned the strength of institutionalised life course stateendorsed policies (such as age norms) in current times. From a macro-structural point of view, the regulatory institutions of social life (e.g. the State or the economy) had become more flexible under the impact of globalisation and post-industrial capitalism (Blossfeld et al. 2005). Alongside economic developments, cultural factors would also exacerbate the gap between the age norms that regulate proper social behaviour and the values of autonomy and self-fulfilment (Settersten and Hagestad 1996, Lawrence 1996). In this line of reasoning, a growing number of authors called our attention to the fluidisation of age markers as a result of the 'postmodernisation of culture' (Eyerman and Turner 1998). From a normative and legal standpoint, institutional processes of 'defamilialisation, as argued by Esping-Anderson (1999), decreased the dependency from the family-group, thereby enabling less regulated and freer individual biographies. From the standpoint of individuals, these social transformations would then translate into a growing diversification of biographies afar from linear temporalities and patterns of full employment or family stability (Cavalli and Fragnière 2003, Guillemard 2005, Widmer et al. 2003, Widmer and Ritschard 2009). Given that the pace of change was affecting different areas of people's lives differently, several authors argued that education, work or family life should be examined separately.

Although a number of authors (Elder and Rockwell 1976, Modell et al. 1976, Pebley 1981, Marini 1984) sustained that age rules tended for stronger rigidity within conjugality and parenthood, others have found the opposite movement. Since the 1970s, it was mainly in the organisation of family life that evidence of change accumulated (e.g. Hogan 1978, Buchmann1989). As more recently noted by Brückner and Mayer (2005: 48-49), for the German case, family life seems more noticeably affected by destandardisation processes when compared with educational or employment trajectories. These findings are nonetheless 
context-specific. At present, the growing precariousness of work trajectories will very likely translate into higher levels of life course destandardisation. The "precarity of life arrangement' (borrowing the concept put forward by Motakef 2019) takes its toll on lifecourse patterns. Pluralisation and flexibilisation of work trajectories is an unavoidable outcome.

Despite the fact that life course destandardisation is the object of some controversy, between favourable arguments (e.g., Pais 2001) and relative rebuttals (e.g., Levy, Widmer and Kellerhals 2002, Levy 2005), the transformations observed in the construction of biographies are undeniable. Like in past times, trajectories would be less predictable and more heterogeneous. Even if there is a lower degree of homogenisation in both past and present, the plurality of contemporary biographies is very different from the life course regimes of the pre-modern days. While in the demographic Ancien Régime, poverty, disease and death constrained people's lives (Ariès 1973 [1960], Gillis 1974), contemporary life courses reflect new social dynamics. For this reason, and aiming to further understand destandardisation, we need comprehensive tools that might help us ascertain the meaning of pluralisation. The findings that follow are an attempt to identify the plurality of life trajectories in the Portuguese case.

\section{Data and methods: family and work trajectories across three generations}

In Portugal, the changes in family life were intense in the past few decades. Following a period of 'family triumphalism' (Almeida et al. 1998, Aboim 2006), marked by an increment in nuptiality and a decrease in the number of children born outside marriage until the 1980s, we witnessed the emergence of new family forms (cohabitation, divorce, family recomposition, same-sex families), into which individuals enter in diversified manners and 
in later stages of life. The present life course regime in Portugal is quite different from that of the past, not only because the modal ages for certain transitions have changed, but also because the once linear sequence between transitions, at least from a normative standpoint, is no longer dominant (Aboim 2010). Nonetheless, even if recent analyses point to the limited pluralisation of family trajectories over time (Ramos 2016, 2019) and to the forced precariousness of labour, there is a dearth of information on life course trajectories.

Our analysis of life-course trajectories drew on representative data from an extensive national survey fielded in 2010. The survey covered three Portuguese generations (500 individuals in each generation): those born between 1935 and 1940, 1950 and 1955 and 1970 and $1975 .{ }^{1}$ Our three-generation sample reflects major historical processes that took place in Portuguese society and have marked the biographies of men and women. The first group of individuals represents a generation born before World War II and raised in the heyday of Salazar's right-wing authoritarian and colonialist regime of the Estado Novo (1926-1974). The second generation is the post-war generation, which enters adult life in the late 1960s, during the final period of the authoritarian regime. This middle generation lived through the troubled times of the transition to democracy, also undergoing the impact of the major changes that occurred in economic, social, political and cultural structures. Finally, the third generation represents an age group that entered adult life in the post-EU period. The beginning of the 1990s was a time of stabilisation and consolidation of the massive social changes that had shaken Portuguese society in earlier decades. Closely following central tenets of the life course approach (Elder 1994), we consider our sample suited for

\footnotetext{
${ }^{1}$ The sample corresponds to a stratified probability sample of Portuguese men and women residing in the country (Response rate equals $60 \%$ and overall sampling error corresponds to $\pm 2,5 \% ; \alpha=0,05$ ). Foreigners and individuals with mental or physical disabilities were defined as not eligible. Interviews were conducted by a group of trained interviewers in the respondents' household and following the PAPI method.
} 
characterising life course trajectories and reassessing (de)standardisation. Our approach to the concept operates with simple measures and statistical tools since we opted for equating destandardisation with the pluralisation of life trajectories. Additionally, the degree of homo or heterogenisation is descriptively identified through the mapping of all the family and work trajectories within our three-generation sample. Above all, we sought to know more about how men and women from different generations lived their lives.

The analysis of life trajectories across and within generations implied three important methodological procedures.

Firstly, with regard to intergenerational comparison, we considered individuals' life courses from ages 0 to 35, although divided into two timeframes. Trajectories up to age 17 cover the period of childhood and adolescence for the three generations, which lived respectively between 1935 and 1957, between 1950 and 1972, and between 1970 and 1992 . Trajectories from ages 18 to 35 encompass the transition to early adulthood and adulthood. In terms of historical time-periods and their correspondence with established typologies of life course regimes over time (e.g. Mayer 2004), the older generation lived through this life phase between 1953 and 1975 (Fordist regime), the middle generation between 1968 and 1990 (transition to post-Fordist regime) and the younger generation between 1988 and 2010 (peak of the post-Fordist regime). These procedures were necessary in order to compare the generations over a similar life-period (length-wise), from childhood to early adulthood. We carried out the analysis using the information that is common to the three generations studied. Respondents were asked to report, year by year, the different situations in which they have lived and worked. Therefore, we took the number of years spent in each situation as our unit of analysis. 
Secondly, alongside the generational design, we analysed different areas of the life course. The differential of plurality in family and work trajectories has convoked scholarly attention, sometimes with contrasting results. While a number of life course theorists argued that private life became the most plural, others pinpointed the growing precariousness of work trajectories produced by the flexibilisation of the labour market. Therefore, the analysis of life courses was expanded to include both the family and private life (namely, conjugal and household trajectories) and the labour market (work trajectories).

Thirdly, we followed an inductive protocol to reconstruct the whole range of trajectories in each generation, including minority patterns that apply to small percentages of individuals. We computed several hierarchical clusters that generated three trajectory typologies $^{2}$ for the three generations. Our analytical strategy reflects our concern with the sociological relevance of the small numbers, often obfuscated when mapping the more common or prevalent sequences of events within a population. ${ }^{3}$ In our view, while still privileging complex sequences of events rather than singular biographical transitions, the characterisation of life course trajectories would be perhaps misleading if we ignored the small numbers and focused only on the life courses of the majority.

Through this procedure, we clustered three different trajectories (up to 35 years old): conjugal life, living arrangements and work trajectories. Conjugal trajectories consider for each individual, the number of years lived in a given situation and map all the reported changes in the relationship status up to age 35 . Different states include courtship, informal

\footnotetext{
2 The cluster analysis was carried out in two stages: we first conducted a hierarchical analysis (using the Ward method) and then used the K-Means Cluster procedure to optimize the classification obtained earlier. This statistical analysis is in line with the research methodology, which does not at the outset limit the number of types, allowing room for new combinations of types of answer.

${ }^{3}$ On the limitations of sequence analysis, such as commonly used Optimal Matching, see Hollister 2009.
} 
relationships without residential cohabitation, cohabitation, marriage (civil and religious), separation, divorce and widowhood. Household living arrangements also consider household constitution for each year of the individuals' biographies. Household trajectories were divided into two different timeframes: co-residence up to age 17 (conventionally a period of dependence) and from ages 18 to 35 (the conventional transition to adulthood). Finally, work trajectories were also analysed through a cluster analysis of the different employment status, occupational situations and type of work contract observed in each year of individuals' biographies up to age 35 . Likewise, work trajectories were divided into the same age-periods mentioned above: up to age 17 and between ages 18 and 35 .

In the section that follows, we describe the trajectories of the three generations surveyed. While historical time across generations and gender differentiation within generations are relevant in our interpretation of Portuguese life course regimes, we follow a descriptive approach. In our analysis, causality is not deemed central inasmuch as description can be as valid a scientific exercise. Furthermore, it fits our main goal. In this sense, we agree with Andrew Abbott who emphasizes the importance of description for doing science (Abbott 2001).

\section{Life-course regimes in Portugal}

\section{Conjugal and relationship trajectories}

A first generational analysis of conjugal trajectories up to age 35 (Table 1) shows a number of key aspects. The central model in any generation is that of a single relationship ending up in marriage (religious and civil). However, the proportion of this type of conjugal life course is very different in the three generations. From 65 per cent in the older generation (71 per cent for women and 56 for men), this trajectory decreases to almost 62 per cent in the 
middle generation (with a slight increase, in men's case, to almost 59 per cent and a decrease in women's to around 64). Strikingly, it covers only 39 per cent of the cases in the younger generation (though still more prominent for women, with almost 45 per cent of women included in this profile). These results seem to confirm the pluralisation of life courses in Portuguese society, at least in what concerns relationship and conjugal trajectories. Gender differences are important to interpret such a social process, as we have to bear in mind that homogenisation of family trajectories was stronger for women than for men.

\section{TABLE 1 AROUND HERE)}

Several findings seem to reinforce the tendency for pluralisation. In the younger generation, we observe the increase of multiple relationships without cohabitation (less than 5 per cent in the older generation, slightly more than 5 per cent in the middle and 14 per cent in the younger generation). Cohabitation also rose from 6 per cent in the older generation to 10 per cent in the middle and 21 per cent in the younger. The growth of all the trajectories marked by divorce or separation is also consistent. Individuals who have lived through several non-cohabiting relationships and marriages ending in divorce amount to less than 4 per cent in the older generation, are almost 7 per cent in the middle and reach 9 per cent in the younger. People with several cohabitations, one or more marriages and more than one divorce or separation are less than 2 per cent in the older generation, around 3 per cent in the middle and almost 6 per cent in the younger generation.

However, homogenisation or standardisation itself must not be accepted as a given fact. Even if some destandardisation of conjugal trajectories seems to be taking place in younger generations, the plurality of life course trajectories is observable in any generation. 
Albeit the fact that, particularly for older generations, many of the non-dominant trajectories were a target for discrimination (including legal discrimination), the truth is that they did exist and introduced sociologically relevant patterns of differentiation within a population.

\section{Household trajectories}

Regarding living arrangements up to age 17, statistical procedures resulted in a fourcategory typology. Each category resulted from the relative proportion, in number of years, of household composition. The first trajectory covers individuals who have mainly lived with both parents, on average 16.8 years out of 17 . The second category, although also presenting the situation of living with both parents on average for about 6.4 years, is characterised by almost 8 years living with a single parent. The third category represents a slightly more complex trajectory - even if living with both parents amounts to around 11 years on average, individuals have also lived alone for around 1 year and also in a couple, either without children (almost 2 years) or with children (about half a year), or a single parent (slightly more than half a year). This trajectory pertains to situations of early departure from parental households, whether to live alone or to enter the conjugal or the parental stages of the life course. The fourth type of living arrangement trajectory up to age 17 aggregates individuals who have co-resided with kin (for 3 half years on average) or non-kin (for almost 7 years). These individuals have lived for only 6 years, on average, with their parents.

The first type of trajectory, living with both parents, is dominant in all generations (Table 2). It comprises around 83 per cent of all cases. Conversely, living with a single parent represents only around 8 per cent of the cases whereas trajectories of early exit from the parental household combined with couple formation or parenthood amount to only 2.5 per cent. Living with others (extended kin and non-kin) covers 6 per cent of the cases. There are, 
however, important differences between generations. Firstly, even if the most conventional and standardised trajectory (living with both parents) is statistically dominant across generations, it increases with generational progression, from 79 per cent in the older generation to slightly more than 83 in the middle one and almost 87 per cent in the younger generation. Inversely, living with a single parent decreases with generational progression, from almost 10 per cent in the older generation to around 8 per cent in the middle and to only 7 per cent in the younger generation. The early exit from the parental household remains relatively constant in all three generations, albeit with a slight intensification in the middle generation, probably because of the enhancement of conjugal standardisation in the 1980s. The more marginal trajectory - living with others, kin or non-kin - decreases with generational progression, from around 9 per cent in the older generation to about 5 and a half per cent in the middle to less than 4 per cent in the younger generation.

\section{(TABLE 2 AROUND HERE)}

Contrasting with conjugal trajectories, where a degree of destandardisation accompanies generational progression, household trajectories, at least until age 17, seem to develop in the opposite direction pointing to the fortification of standardisation processes.

\section{(TABLE 3 AROUND HERE)}

In household trajectories from ages 18 to 35 , the panorama is definitely more complex (Table 3). The typology produced also by cluster analysis comprises nine types of household trajectories. 
The first type of trajectory - living alone (on average for 10 out of 17 years) - steadily increased with generational progression, from 4 per cent in the older generation to 6 in the middle one and finally to 12.5 per cent in the younger generation. The second trajectory, living in a couple with children (for almost 13 years on average) depicts early entries into conjugal life and parenthood. Early conjugal life with children rose from almost 38 per cent in the older generation to 46 per cent in the middle, thus portraying the reinforcement of standardisation in this generation. Then it decreased sharply to less than 27 per cent in the younger generation. The third pattern, living with a single parent ( for almost 9 years) is a type of trajectory that suffered little change, decreasing from around 7 per in the older generation to 5 per cent in the middle and younger ones. A similar trend is visible in the fourth trajectory, living with non-relatives (for almost 8 years on average) decreased from around 6 per in the older generation to 4 and a half per cent in the middle and younger generations. Likewise, the same generational pattern marks the trajectories of those who lived with extended kin (for about 9 years) from ages 18 to 35: this pattern decreased from around 5.5 per cent in the older generation to around 3 per cent in the middle and younger ones. From an inter-generational perspective, it must be noted that the latter three types had a heavier weight in the older generation. More importantly, these findings lead us to signal, for the Portuguese case, the incidence of destandardisation processes in the golden historical period of the Fordist life course regime, from the early 1950s to the mid-1970s. In Portugal, one-third (30.3 per cent) of men and women lived outside a conjugal household at the margins of the normative standard of the time.

On the other hand, living as a single parent (for 7 years on average) remained constant in the first two generations (around slightly more than 3 and a half per cent), but increased in the younger generation, amounting to almost 8 per cent of the cases in our sample. Living in 
a couple without children (on average, 11 and a half years), which amounted to slightly more than 8 per cent in the older generation, decreased to around 5 per cent in the middle and younger generations. Surprisingly, the delayed conjugal and parental trajectory remained quite constant: 24 per cent in the older generation, about 23 per cent in the middle generation and 27 per cent in the younger generation. In the latter generation, this model is as significant - or even slightly more represented - than the early conjugal and parental model. The importance of delayed transitions in the younger generation is also demonstrated by the increase in the ninth type of trajectory, remaining with both parents (on average for nearly 17 years), which rose from around 4 per cent in the two older generations to almost 9 per cent in the younger one.

If household trajectories up to age 17 revealed an overall generational process of standardisation, when dealing with household trajectories from ages 18 to 35 we are faced with a different scenario. In fact, destandardisation seems to increase in the younger generation, with the clear postponement of conjugal and parental transitions, which signals, in our view, what could be seen as the emergence of a 'new standard' in the building up of the life course. However, it is not in the older generation that we found the peak of standardisation, but rather in the middle one, with the reinforcement of early entries into conjugal life and parenthood. This movement was also accompanied by a visible diminution of diversity.

\section{Work trajectories}

Work trajectories up to age 17 (Table 4) are depicted through a six category typology. As expected, there are sharp differences between generations. The first type of trajectory encompasses individuals who, in the period of childhood and adolescence, were essentially 
students (on average almost 10 years out of 17), representing around 27 per cent of all cases. As a result of the massive expansion of the school system, the student trajectory rose from 10.5 per cent in the older generation to almost 21 per cent in the middle and to 47 per cent in the younger generation. Inversely, casual workers (people who jolted from employment to unemployment and endured significant levels of contract precariousness) decreased from 7 per cent in the older generation to around 4 per cent in the two younger generations. The trajectory of precarious work after a somewhat short schooling career (no more than 6 years on average) seems to maintain some stability, ranging from almost 28 per cent in the older generation to 29 in the middle and decreasing slightly to 24 per cent in the younger generation. The fourth trajectory represents non-precarious workers who were also students for a significant time-period (slightly more than 6 years on average) and amounts to 14 per cent of the cases. The non-precarious trajectory, which covered a mere 7 per cent of the cases in the older generation, rose to almost 19 per cent in the middle generation and slightly decreased to almost 16 in the younger one. The housewife profile is one that progressively weakened from the older to the younger generation, decreasing from 7 per cent in the older generation to less than 5 per cent in the middle one and representing only around 2 per cent

of the cases in the younger generation. The trajectory of precarious work (where schooling lasted just 2 and a half years, on average) also tended to suffer a significant erosion, going from a staggering 41 per cent of cases in the older generation to 23 per cent in the middle one, and to less than 8 per cent in the younger generation.

\section{(TABLE 4 AROUND HERE)}


Work trajectories up to age 17 reveal a pattern of progressive standardisation of the life course in the early years of life, accompanying the stronger regulation of childhood and adolescence as school years. More plurality and diversity - and, in fact, destandardisation in the pre-Fordist sense - existed in the older generation. However, the higher level of plurality in the older generation was mainly caused by situations of relative poverty and social exclusion that compelled children and young people to enter the labour market, generally with high levels of precariousness. With the growing attendance to school, this pattern of a 'working childhood' suffered a profound erosion and is clearly a minority in the younger generation.

In work trajectories from ages 18 to 35 , the panorama is not the same. Between 18 and 35 , destandardisation seems to increase in the younger generation, after a moderate increase of standardisation in the middle generation. Cluster analysis produced a six-category typology (Table 5).

\section{(TABLE 5 AROUND HERE)}

Generational differences remain important in the period of early adulthood, although for very different reasons. Compared with work trajectories in childhood and adolescence, generational differences are stronger from ages 18 to 35 .

Firstly, the housewife trajectory (on average almost 13 out of 17 years) suffered a very significant erosion, ranging from almost 17 per cent in the older generation to only slightly more than 12 per cent in the middle and to around 4 per cent in the younger generation. The second type is residual and mixes a number of different situations across the

life span (namely students, military and unemployed). Trajectories of individuals who were 
students, then military and afterwards unemployed remains relatively constant under 2 per cent. Trajectories characterised by a schooling period (almost 7 years on average) followed by dependent work with a stable contract (almost 11 years on average) increases alongside generational progression, from a scarce 3 per cent in the older generation to more than 9 per cent in the middle, up to almost 21 per cent in the younger generation. The fourth type of work trajectory represents around 17 per cent of the cases and includes individuals who we called 'bumpy workers'. Bumpy workers spent 15 years of their young adulthood working and have experienced a high number of transitions, both non-precarious and precarious. Precarious work situations were nonetheless more durable (almost 9 years, on average). Bumpy workers decrease from the older to the middle generation, from almost 13 per cent to slightly more than 10 per cent, but again rise to a striking 27 per cent of the cases in the younger generation. The fifth type portrays non-dependent workers, namely employers, but essentially self-employed, amounting to 15 per cent of all cases. Amounting to more than 20 per cent in the older generation (with self-employment being a typical and traditional escape from precariousness), non-dependent workers decreased steadily with generational progression. Finally, stable workers slightly increased from the older to the middle generation, from almost 46 per cent to around 51 per cent, and decreases significantly to just 36 per cent in the younger generation. Still, this is the most representative category even in this generation.

Two trends are important. From the older to the middle generation, we can observe an increase in the standardisation of work trajectories. From the middle to the younger generation, the movement is in the opposite direction - destandardisation increases. Nonetheless, plurality and diversity remain a mark in all three generations. 


\section{Final Remarks}

When read under the lens of conventional (de)standardisation theories, our analysis of conjugal, household and work trajectories revealed mixed developments. Conjugal trajectories appear more evidently permeable to the flow of historical change (like individualisation or deinstitutionalisation) and a degree of destandardisation seems to develop with generational progression. A similar conclusion is applicable to living arrangements and work trajectories between ages 18 to 35. Destandardisation appears also to increase in the younger generation, pointing out the rapid pace of change in Portuguese society between 1988 and 2010. The peak of standardisation in living arrangements and work trajectories from ages 18 to 35 is not, however, in the older generation, but in the middle one. Demonstrating that the highly standardised Fordist life course regime only partially and belatedly occurred in Portugal, it is among individuals born between 1950 and 1955 who went through early adulthood in the 1970s and 1980s, that we observe a reinforcement of conjugality and parenthood as well as an increase in work stability. In turn, standardisation of household and work trajectories up to age 17 increases with generational progression. Overall, when we analyse children's and adolescents' life courses, the younger generation seems to be marked by a stronger standardisation process, which accords with the parallel development of pluralisation and 'chronological' institutionalisation of the life course, as argued by Kohli (1986, 2007).

In sum, the reading of social transformation in life course regimes is rather complex. In spite of the different dynamics found in different areas of the life course, with more standardisation in some spheres, age-periods and generations, and more destandardisation in others, processes of homogenisation and heterogenisation appear interwoven across generations. In effect, we cannot overrate either the pluralisation or the uniformisation of 
trajectories. Nor overestimate the relevance of pluralisation and uniformisation per se. A more fitting conclusion should emphasize the concomitancy of standardisation and pluralisation within the trajectories of all the three generations. The two deemed opposite processes appear more entangled than visibly separated. Hence, the identification of a particular life course regime has to deal with both the predominant and the minority trajectories, which are particular to a specific historical period.

However, beyond the empirical portrait of life courses and while acknowledging the descriptive nature of our statistical approach, the plurality of trajectories obliges us to criticize the very idea of a linear standardisation process in the past or the idea of a straightforward de-standardisation in younger generations. Therefore, more than just adjusting the destandardisation hypothesis to the Portuguese empirical reality, we suggest that (de)standardisation itself must be redressed. Perhaps destandardisation and standardisation are not conceptually fit to account for transformations in the lives of individuals across time. On the one hand, pluralisation and heterogenisation of life situations might have radically different meanings. On the other hand, this set of concepts have not yet fully escaped the influence of the Parsonian emphasis on order. After all, the centrality of the Fordist industrial model of the Post-WWII period is not random. Although historically exceptional, short-lived and geographically limited to a few societies of the centre, it is against this life course regime that other dynamics are interpreted and classified as pre and post the Fordist regime of rich industrialised societies of the Golden Age (Ramos 2019, 17). An additional, though correlated, problem relates to the measures of (de)standardisation. Often, the act of measuring the plurality of lives implies that we select a certain ideal model as the normal standard against which other trajectories are supposed to be measured. Such a procedure hides the imposition of a normative social order that tends to 
be conservative. Often, the standard is kept as the 'centre' even against empirical evidence that proves otherwise. Even when a relative majority of people does not follow the so-called standard.

Finally, in future research, we need to reassess linear views of the succession of relatively coherent life course regimes over time. Patterns and regimes are hardly applicable to all societies. Furthermore, for the most part, empirical reality does not lend itself to replicate theoretical models built upon premises of limited scope for analysing societies outside typical industrialised centres. Most importantly, life course regimes may portray a certain reality (normative or statistically dominant in a given moment and space), but they are never simply internally homogeneous or heterogeneous. Rather, to a greater or lesser extent, the two dynamics coexist. Therefore, plurality is not always synonymous for linear destandardisation, in the same way that uniformity cannot be acritically seen as indicative of linear standardisation.

\section{Acknowledgements}

This paper drew on data collected in the frame of a research project on 'Family trajectories and social networks: the life course in an intergenerational perspective', which was funded by the Portuguese Science Foundation ((PTDC/SDE/65663/2006) and coordinated by Karin Wall at the Institute of Social Sciences of the University of Lisbon between 2008 and 2012.

\section{References}

Abbott, Andrew (2001). Time Matters: On Theory and Method. Chicago: University of Chicago Press.

Aboim, Sofia (2006). Conjugalidades em Mudança. Percursos e Dinâmicas da Vida a Dois. Lisbon: Imprensa de Ciências Sociais. 
Alexander, Jeffrey (2014). Modern Reconstruction of Classical Thought: Talcott Parsons. London: Routledge.

Almeida, Ana Nunes, Maria das Dores Guerreiro, Cristina Lobo, Anália Torres and Karin Wall (1998). Relações Familiares: Mudança e Diversidade. In Portugal, que Modernidade?, orgs., José Manuel Leite Viegas and António Firmino da Costa, 45-78. Oeiras: Celta.

Ariès, Philippe (1973 [1960]). L'enfant et la vie familiale sous l'Ancien Régime. Paris: Seuil.

Bauman, Zygmunt (2001). The individualised society. Cambridge: Polity Press.

Bauman, Zygmunt (2004). Identity: conversations with Benedetto Vecchi. London: WileyBlackwell.

Beck, Ulrich and Elizabeth Beck-Gernsheim (2002). Individualisation. London: Sage.

Beck, Ulrich (2000). Living Your Own Life in a Runaway World: Individualisation, Globalisation, and Politics. In Global Capitalism, eds., Will Hutton and Anthony Giddens, 164-174. New York: The New Press.

Blossfeld, Hans-Peter, Erik Klijzing, Melinda Mills and Karin Kurz (2005). Globalisation, Uncertainty and Youth in Society. London: Routledge.

Brückner, Hannah, e Karl Ulrich Mayer (2005). De-standardisation of the life course: what it might mean? And if it means anything, whether if actually took place? In The Structure of the Life Course: Standardised? Individualised? Differentiated?, ed., Ross Macmillan, 27-53. London: Elsevier.

Buchmann, Marlis (1989). The script of life in modern societies. Entry into Adulthood in a Changing World. Chicago: University of Chicago Press. 
Cavalli, Stefano and Jean-Pierre Fragnière (2003). L'avenir. Attentes, projets,(dés)illusions, ouvertures. Lausanne: Editions Réalités Sociales.

Craib, Ian (1998). Experiencing Identity. London: Sage.

Elder, Glen H. and Richard C. Rockwell (1976). Marital Timing in Women's Life Patterns. Journal of Family History 1: 34-53.

Elder, G. H. (1994). Time, Human Agency, and Social Change: Perspectives on the Life Course. Social Psychology Quarterly, 57(1): 4-15.

Elder, Glen. H., Jr., Monica K. Johnson and Robert Crosnoe (2003). The Emergence and Development of the Life Course. In Handbook of the Life Course, eds., Jeylan T. Mortimer e Micael J. Shanahan (eds.), 3-18. Nova Iorque: Kluwer.

Elias, Norbert (1993). A Sociedade dos Indivíduos. Lisbon: Dom Quixote.

Esping-Andersen, Gøsta. 1999. Social Foundations of Postindustrial Economies. Oxford: Oxford University Press.

Giddens, Anthony (1992). As Consequências da Modernidade. Oeiras: Celta.

Giele, Janet Zollinger (2004). Women and Men as Agents of Change in Their Own Lives. In Changing Life Patterns in Western Industrial Societies. Vol. 8 of Advances in Life Course Research, eds., Janet Z. Giele e Edward Holst, 299-317, Amsterdam: Elsevier.

Gillis, John (1974) Youth and History: Tradition and Change in European Age Relations, 1770-Present. New York: Academic Press. 
Guillemard, Anne-Marie (2005). The advent of a flexible life-course and the reconfiguration of welfare. In The New Face of Welfare, eds., Jorgan G. Andersen, Anne-Marie Guillemard, Per H. Jensen e Birgit Pfau-Effinger, 53-72. Manchester: Policy Press.

Heelas, Paul (1996). Detraditionalisation and its Rivals. In Detraditionalisation, eds. Paul Heelas, Scott Lash and Paul Morris, 1-20. London: Blackwell.

Heinz, Walter R. and Helga Krüger (2001). Life Course: Innovations and Challenges for Social Research. Current Sociology, 49 (2): 29-45.

Hill, Reuben and Roy Rogers (1964). The Developmental Approach. In Handbook of Marriage and the Family, eds., Harold T. Christensen, 171-211. Chicago: Rand McNally.

Hogan, Dennis P. (1978). The Variable Order of Events in the Life Course. American Sociological Review 43: 573-86.

Hogan, Dennis P. (1981). Transitions and Social Change: The Early Lives of American Men. New York: Academic Press.

Hollister, Matissa (2009). Is Optimal Matching Suboptimal? Sociological Methods \& Research, 38(2): 235-264.

Kertzer, David I. (1989). Age structuring in comparative and historical perspective. In Age Structuring in Comparative Perspective, eds. David I. Kertzer and K. Warner Schaie, .320. Hillsdale: Erlbaum.

Kohli, Martin (1986). Social Organisation and Subjective Construction of the Life course. In Human Development and the Life Course: Multi disciplinary Perspectives, eds. Aage B. Sørensen, Franz E. Weinert, Lonnie R. Sherrod, 271-92. Hillsdale: Erlbaum. 
Kohli, Martin (2007). The Institutionalisation of the Life Course: Looking Back to Look Ahead. Research in Human Development 4(3-4): 253-271

Lawrence, Barbara S. (1996). Organisational Age Norms: Why Is It So Hard To Know One When You See One? The Gerontologist 36: 209-220.

Levy, René, Eric Widmer and Jean Kellerhals (2002). Modern family or modernised family traditionalism?: Master status and the gender order in Switzerland. Electronic Journal of Sociology [http://www.sociology.org/content/vol006.004/lwk.html].

Levy, René (2005). Phases of individual and family life, and sex-specific master statuses. Lisbon Workshop on Contemporary Families of the ESA RN9. Lisbon: ICS.

Marini, Margaret Mooney (1984). Age and Sequencing Norms in the Transition to Adulthood. Social Forces 63: 229-244.

Mayer, Karl Ulrich, and Walter Muller W. (1986). The state and the structure of the life course. In Human Development and the Life Course. Multidisciplinary Perspectives, eds., Aage B. Sørensen, Franz E. Weinert e Lonnie R. Sherrod, 217-45. Hillsdale: Erlbaum.

Mayer, Karl Ulrich (2004). Whose Lives? How History, Societies, and Institutions Define and Shape Life Courses. Research in Human Development 1(3): 161-187.

Modell, John, Frank Furstenberg, Jr., and Theodore Hershberg (1976). Social Change and Transitions to Adulthood in Historical Perspective. Journal of Family History 1: 7-32.

Möhring, K. (2016). Life course regimes in Europe: Individual employment histories in comparative and historical perspective. Journal of European Social Policy, 26(2), 124139. 
Motakef, Mona (2019). Recognition and precarity of life arrangement: towards an enlarged understanding of precarious working and living conditions. Distinktion: Journal of Social Theory, 20:2, 156-172.

Pais, José Machado (2001). Ganchos, Tachos e Biscate. Jovens, Trabalho e Futuro. Porto: Âmbar.

Pebley, Ann R. (1981). Changing Attitudes Toward the Timing of First Births. Family Planning Perspectives 13: 171-175.

Ramos, Vasco (2016). A pluralização limitada de trajetórias familiares em Portugal. Sociologia, Revista da Faculdade de Letras da Universidade do Porto. Número Temático - Famílias e Curso de Vida. Potencialidades, limites e desafios metodológicos: 38 - 57.

Ramos, Vasco (2019). The de-standardisation of the life course in Portugal. A cross-cohort analysis using entropy analysis. Advances in Life Course Research Vol. 42, 100291 (pre-print version).

Settersten, Richard A., Jr. and Gunhild O. Hagestad (1996). What's the Latest? Cultural Age Deadlines for Family Transitions. The Gerontologist 36:178-188.

Shanahan, Michael J. (2000). Pathways to adulthood in changing societies: variability and mechanisms in life course perspective. Annual Review of Sociology 26: 667-692.

Therborn, Göran (2003). “Entangled Modernities.” European Journal of Social Theory 6 (3): 293-305.

Wagner, Peter (1994). A Sociology of Modernity: Liberty and Discipline. Londres: Routledge. 
Widmer, Eric D. and Ritschard, Gilbert (2009). The de-standardisation of the life course: Are men and women equal? Advances in Life Course Research, 14: 28-39.

Widmer Eric, René Levy, Alexandre Pollien, Raphaël Hammer and Jacques-Antoine Gauthier (2003). Entre standardisation, individualisation et sexuation: une analyse des trajectoires personnelles en Suisse. Revue suisse de sociologie 29(1): 35-67. 


\section{TABLES}

Table 1

Conjugal trajectories up to age 35 by generation and gender

\begin{tabular}{|c|c|c|c|c|c|c|c|c|c|c|c|c|}
\hline & \multicolumn{3}{|c|}{$\begin{array}{l}\text { Generation } \\
1935-1940 \\
\end{array}$} & \multicolumn{3}{|c|}{$\begin{array}{l}\text { Generation } \\
1950-1955 \\
\end{array}$} & \multicolumn{3}{|c|}{$\begin{array}{l}\text { Generation } \\
1970-1975 \\
\end{array}$} & \multicolumn{3}{|c|}{ Total } \\
\hline & $\mathrm{M}$ & $\mathrm{F}$ & Total & $\mathrm{M}$ & $\mathrm{F}$ & Total & $\mathrm{M}$ & $\mathrm{F}$ & Total & $\mathrm{M}$ & $\mathrm{F}$ & Total \\
\hline Without relationships & 1.6 & 4.6 & 3.4 & 1.4 & 2.9 & 2.3 & 1.9 & 2.7 & 2.4 & 1.7 & 3.3 & 2.7 \\
\hline $\begin{array}{l}\text { Relationships without } \\
\text { cohabitation }\end{array}$ & 6.0 & 3.8 & 4.7 & 5.7 & 5.2 & 5.4 & 17.0 & 12.4 & 14.2 & 9.7 & 7.5 & 8.3 \\
\hline 1 marriage & 56.3 & 71.1 & 65.0 & 58.5 & 64.1 & 61.8 & 30.1 & 44.8 & 39.2 & 48.1 & 59.1 & 54.7 \\
\hline $\begin{array}{l}\text { Several relationships. } 1 \\
\text { marriage }\end{array}$ & 22.4 & 10.6 & 15.5 & 14.6 & 8.5 & 11.0 & 10.7 & 6.7 & 8.2 & 15.6 & 8.5 & 11.3 \\
\hline Just cohabitation & 4.4 & 7.6 & 6.3 & 8.0 & 10.8 & 9.7 & 22.3 & 20.6 & 21.3 & 11.8 & 13.5 & 12.8 \\
\hline $\begin{array}{l}\text { Several relationships. marriages } \\
\text { with divorce }\end{array}$ & 7.7 & 0.8 & 3.6 & 6.6 & 6.9 & 6.8 & 10.7 & 8.2 & 9.1 & 8.3 & 5.6 & 6.7 \\
\hline $\begin{array}{l}\text { Several cohabitations. } 1 \text { or more } \\
\text { marriages and } \\
\text { divorces/separations }\end{array}$ & 1.6 & 1.5 & 1.6 & 5.2 & 1.6 & 3.1 & 7.3 & 4.5 & 5.6 & 4.8 & 2.7 & 3.5 \\
\hline Total & 100.0 & 100.0 & 100.0 & 100.0 & 100.0 & 100.0 & 100.0 & 100.0 & 100.0 & 100.0 & 100.0 & 100.0 \\
\hline
\end{tabular}

Table 2

Living arrangements up to age 17 by generation and gender

\begin{tabular}{|c|c|c|c|c|c|c|c|c|c|c|c|c|}
\hline & \multicolumn{3}{|c|}{$\begin{array}{l}\text { Generation } \\
1935-1940\end{array}$} & \multicolumn{3}{|c|}{$\begin{array}{l}\text { Generation } \\
1950-1955\end{array}$} & \multicolumn{3}{|c|}{$\begin{array}{l}\text { Generation } \\
1970-1975\end{array}$} & \multicolumn{3}{|c|}{ Total } \\
\hline & M & $\mathrm{F}$ & Total & M & $\mathrm{F}$ & Total & $\mathrm{M}$ & $\mathrm{F}$ & Total & $\mathrm{M}$ & $\mathrm{F}$ & Total \\
\hline With both parents & 79.8 & 78.7 & 79.1 & 84.9 & 82.4 & 83.4 & 92.2 & 83.3 & 86.8 & 85.9 & 81.6 & 83.3 \\
\hline With single parent & 10.4 & 9.1 & 9.6 & 8.0 & 7.8 & 7.9 & 4.4 & 9.1 & 7.3 & 7.5 & 8.7 & 8.2 \\
\hline $\begin{array}{l}\text { Alone with children and/or in } \\
\text { couple }\end{array}$ & 3.3 & 1.1 & 2.0 & 3.3 & 3.3 & 3.3 & 1.0 & 2.7 & 2.1 & 2.5 & 2.4 & 2.5 \\
\hline $\begin{array}{l}\text { With other people (kin and } \\
\text { others) }\end{array}$ & 6.6 & 11.0 & 9.2 & 3.8 & 6.5 & 5.4 & 2.4 & 4.8 & 3.9 & 4.2 & 7.2 & 6.0 \\
\hline Total & 100.0 & 100.0 & 100.0 & 100.0 & 100.0 & 100.0 & 100.0 & 100.0 & 100.0 & 100.0 & 100.0 & 100.0 \\
\hline
\end{tabular}

Overall inter-generational comparison: $\mathrm{X}^{2}(6,1500) 17.32, \mathrm{p}<.001$ 
Table 3

Living arrangements between ages 18 to 35 by generation and gender

\begin{tabular}{|c|c|c|c|c|c|c|c|c|c|c|c|c|}
\hline & \multicolumn{3}{|c|}{$\begin{array}{c}\text { Generation } \\
1935-1940\end{array}$} & \multicolumn{3}{|c|}{$\begin{array}{l}\text { Generation } \\
1950-1955 \\
\end{array}$} & \multicolumn{3}{|c|}{$\begin{array}{l}\text { Generation } \\
1970-1975\end{array}$} & \multicolumn{3}{|c|}{ Total } \\
\hline & $\mathrm{M}$ & $\mathrm{F}$ & Total & $\mathrm{M}$ & $\mathrm{F}$ & Total & $\mathrm{M}$ & $\mathrm{F}$ & Total & $\mathrm{M}$ & $\mathrm{F}$ & Total \\
\hline Alone & 8.2 & 1.1 & 4.0 & 10.4 & 2.9 & 6.0 & 14.6 & 11.2 & 12.5 & 11.1 & 5.5 & 7.7 \\
\hline Couple with children & 25.1 & 46.4 & 37.7 & 27.4 & 59.2 & 46.1 & 17.5 & 32.1 & 26.5 & 23.3 & 45.5 & 36.6 \\
\hline With single parent & 7.7 & 6.8 & 7.2 & 5.2 & 4.2 & 4.6 & 6.3 & 3.9 & 4.9 & 6.3 & 4.9 & 5.5 \\
\hline With others & 8.2 & 4.6 & 6.1 & 4.2 & 4.6 & 4.4 & 5.3 & 3.9 & 4.5 & 5.8 & 4.3 & 4.9 \\
\hline With kin & 6.6 & 4.6 & 5.4 & 3.3 & 2.6 & 2.9 & 2.4 & 3.3 & 3.0 & 4.0 & 3.4 & 3.7 \\
\hline Single parent & 0.5 & 5.7 & 3.6 & 1.9 & 4.9 & 3.7 & 1.5 & 11.8 & 7.8 & 1.3 & 7.7 & 5.1 \\
\hline Couple without children & 5.5 & 10.3 & 8.3 & 7.1 & 3.9 & 5.2 & 5.8 & 4.5 & 5.0 & 6.2 & 6.0 & 6.1 \\
\hline $\begin{array}{l}\text { With both parents. couple } \\
\text { without children and couple } \\
\text { with children }\end{array}$ & 33.3 & 17.1 & 23.8 & 35.8 & 13.4 & 22.6 & 33.5 & 23.0 & 27.1 & 34.3 & 18.0 & 24.5 \\
\hline With both parents & 4.9 & 3.4 & 4.0 & 4.7 & 4.2 & 4.4 & 13.1 & 6.1 & 8.8 & 7.7 & 4.7 & 5.9 \\
\hline Total & 100.0 & 100.0 & 100.0 & 100.0 & 100.0 & 100.0 & 100.0 & 100.0 & 100.0 & 100.0 & 100.0 & 100.0 \\
\hline
\end{tabular}

Overall inter-generational comparison: $\mathrm{X}^{2}(16,1500)=95.20, \mathrm{p}<.000$

Table 4

Work trajectories up to age 17 by generation and gender

\begin{tabular}{|c|c|c|c|c|c|c|c|c|c|c|c|c|}
\hline & \multicolumn{3}{|c|}{$\begin{array}{l}\text { Generation } \\
1935-1940 \\
\end{array}$} & \multicolumn{3}{|c|}{$\begin{array}{l}\text { Generation } \\
1950-1955 \\
\end{array}$} & \multicolumn{3}{|c|}{$\begin{array}{l}\text { Generation } \\
1970-1975 \\
\end{array}$} & \multicolumn{3}{|c|}{ Total } \\
\hline & $\mathrm{M}$ & $\mathrm{F}$ & Total & $\mathrm{M}$ & $\mathrm{F}$ & Total & $\mathrm{M}$ & $\mathrm{F}$ & Total & $\mathrm{M}$ & $\mathrm{F}$ & Total \\
\hline Students & 9.8 & 11.0 & 10.5 & 20.3 & 21.2 & 20.8 & 40.3 & 51.2 & 47.0 & 24.0 & 29.3 & 27.1 \\
\hline Casual workers & 10.4 & 4.6 & 7.0 & 3.8 & 4.9 & 4.4 & 4.4 & 3.6 & 3.9 & 6.0 & 4.3 & 5.0 \\
\hline $\begin{array}{l}\text { Students and then precarious } \\
\text { workers }\end{array}$ & 27.3 & 28.1 & 27.8 & 26.4 & 30.4 & 28.8 & 28.6 & 20.9 & 23.9 & 27.5 & 26.3 & 26.7 \\
\hline Non-precarious workers & 8.7 & 6.1 & 7.2 & 21.7 & 16.7 & 18.7 & 18.0 & 13.9 & 15.5 & 16.5 & 12.6 & 14.1 \\
\hline Housewives & 1.1 & 11.0 & 7.0 & & 7.8 & 4.6 & & 3.6 & 2.2 & .3 & 7.2 & 4.5 \\
\hline Precarious workers & 42.6 & 39.2 & 40.6 & 27.8 & 19.0 & 22.6 & 8.7 & 6.7 & 7.5 & 25.8 & 20.4 & 22.5 \\
\hline Total & 100.0 & 100.0 & 100.0 & 100.0 & 100.0 & 100.0 & 100.0 & 100.0 & 100.0 & 100.0 & 100.0 & 100.0 \\
\hline
\end{tabular}

Overall inter-generational comparison: $\mathrm{X}^{2}(10,1500)=292.85, \mathrm{p}<.000$ 
Table 5

Work trajectories between ages 18-35 by generation and gender

\begin{tabular}{|c|c|c|c|c|c|c|c|c|c|c|c|c|}
\hline & \multicolumn{3}{|c|}{$\begin{array}{l}\text { Generation } \\
1935-1940\end{array}$} & \multicolumn{3}{|c|}{$\begin{array}{l}\text { Generation } \\
1950-1955\end{array}$} & \multicolumn{3}{|c|}{$\begin{array}{l}\text { Generation } \\
1970-1975\end{array}$} & \multicolumn{3}{|c|}{ Total } \\
\hline & $\mathrm{M}$ & $\mathrm{F}$ & Total & $\mathrm{M}$ & $\mathrm{F}$ & Total & M & $\mathrm{F}$ & Total & $\mathrm{M}$ & $\mathrm{F}$ & Total \\
\hline Housewives & 1.1 & 27.8 & 16.8 & 1.4 & 19.6 & 12.2 & .5 & 6.7 & 4.3 & 1.0 & 17.2 & 10.7 \\
\hline $\begin{array}{l}\text { Students. military and } \\
\text { unemployed }\end{array}$ & 1.1 & 1.9 & 1.6 & 2.4 & 1.0 & 1.5 & 1.0 & 2.4 & 1.9 & 1.5 & 1.8 & 1.7 \\
\hline Students and then workers & 3.8 & 2.7 & 3.1 & 9.4 & 9.2 & 9.3 & 18.9 & 22.1 & 20.9 & 11.0 & 12.0 & 11.6 \\
\hline Bumpy workers & 20.8 & 6.8 & 12.6 & 14.6 & 7.5 & 10.4 & 27.7 & 27.0 & 27.2 & 21.0 & 14.5 & 17.1 \\
\hline Non-dependent workers & 29.5 & 14.1 & 20.4 & 28.3 & 6.5 & 15.4 & 13.6 & 7.9 & 10.1 & 23.6 & 9.2 & 15.0 \\
\hline Stable workers & 43.7 & 46.8 & 45.5 & 43.9 & 56.2 & 51.2 & 38.3 & 33.9 & 35.6 & 41.9 & 45.3 & 43.9 \\
\hline Total & 100.0 & 100.0 & 100.0 & 100.0 & 100.0 & 100.0 & 100.0 & 100.0 & 100.0 & 100.0 & 100.0 & 100.0 \\
\hline
\end{tabular}

